\title{
ERRATUM
}

\section{Erratum to: Observational evidence of the Yellow Sea warm current}

YU Fei (于非), ZHANG Zhixin (张志欣), DIAO Xinyuan (フ新源), GUO Jingsong (郭景松)

CC Chinese Society for Oceanology and Limnology, Science Press, and Springer-Verlag Berlin Heidelberg 2010

Erratum to: Chinese Journal of Oceanology and Limnology

Vol. 28 No. 3, P. 677-683, 2010

DOI: 10.1007/s00343-010-0006-2

In the original article, the second line of the heading on Page 677 contains errors. The correct one should read "Vol. 28 No. 3, P. 677-683, 2010". The publishing companies apologize to the authors and the readers.

The online version of the original article can be found at http://dx.doi.org/10.1007/s00343-010-0006-2 